\title{
Diminished mTOR signaling: a common mode of action for endocrine longevity factors
}

\author{
Dudley W Lamming ${ }^{1,2}$
}

\begin{abstract}
Since the initial observation that a calorie-restricted (CR) diet can extend rodent lifespan, many genetic and pharmaceutical interventions that also extend lifespan in mammals have been discovered. The mechanism by which CR and these other interventions extend lifespan is the subject of significant debate and research. One proposed mechanism is that CR promotes longevity by increasing insulin sensitivity, but recent findings that dissociate longevity and insulin sensitivity cast doubt on this hypothesis. These findings can be reconciled if longevity is promoted not via increased insulin sensitivity, but instead via decreased PI3K/Akt/mTOR pathway signaling. This review presents a unifying hypothesis that explains the lifespan-extending effects of a variety of genetic mutations and pharmaceutical interventions and points towards new molecular pathways which may also be leveraged to promote healthy aging.
\end{abstract}

Keywords: Calorie restriction; Rapamycin; Insulin resistance; Longevity

\section{Introduction}

Calorie restriction (CR), first discovered to extend rat lifespan in the 1930's, is one of the most effective known techniques for promoting longevity (McCay et al. 1939). A CR diet, in which total caloric intake is reduced while maintaining adequate nutrition, promotes lifespan not only in rats, but in yeast, worms, flies, dogs, and even primates (Lamming and Anderson 2014). A CR diet also increases healthspan - that portion of a life where one is healthy and vigorous. The mechanism underlying the effect of a CR diet on longevity has been hotly debated, with suggestions ranging from a passive mechanism in which CR slows metabolism, to a more active mechanism in which a CR diet induces protective stress response pathways (Anderson and Weindruch 2010; Sinclair 2005).

A conserved response to $\mathrm{CR}$ in mammals, including humans as well as non-human primates, is a significant increase in insulin sensitivity (Kemnitz et al. 1994; Cartee et al. 1994). As high-fat, obesity-promoting diets clearly inhibit insulin sensitivity as well as lifespan (Olefsky and Glass 2010), it is logical to suppose that the enhanced insulin sensitivity induced by CR may be responsible for its

\footnotetext{
Correspondence: dlamming@medicine.wisc.edu

'Division of Endocrinology, Department of Medicine, University of

Wisconsin-Madison, Madison, Wisconsin, USA

${ }^{2}$ William S. Middleton Memorial Veterans Hospital, Madison, Wisconsin, USA
}

effects on healthspan and lifespan. In favor of this hypothesis, the Ames and Snell dwarf mice, which have an exceptionally long lifespan, likewise display significantly increased insulin sensitivity (Bartke and Brown-Borg 2004). However, as discussed below, data from genetically modified organisms and the surprising effects of the prolongevity drug rapamycin on insulin sensitivity show that these effects can be disassociated. The common feature behind many insulin-sensitizing and insulin-desensitizing longevity interventions is decreased mTOR pathway signaling, suggesting that endocrine factors which directly or indirectly regulate mTOR signaling may be potential regulators of longevity.

\section{Review}

Reduced activity of the PI3K/Akt/mTOR signaling pathway promotes longevity

Reduced signaling through the insulin/IGF-1/mTOR (insulin-like growth factor $1 /$ mechanistic Target Of Rapamycin) signaling pathway has been proposed as an essential mechanism by which a CR diet extends lifespan (Lamming and Anderson 2014). Consistent with this theory, both genetic and pharmacological interventions that reduce signaling through the insulin/ IGF-1/mTOR signaling pathway extend lifespan. As detailed in Figure 1, genetic interventions in this pathway 


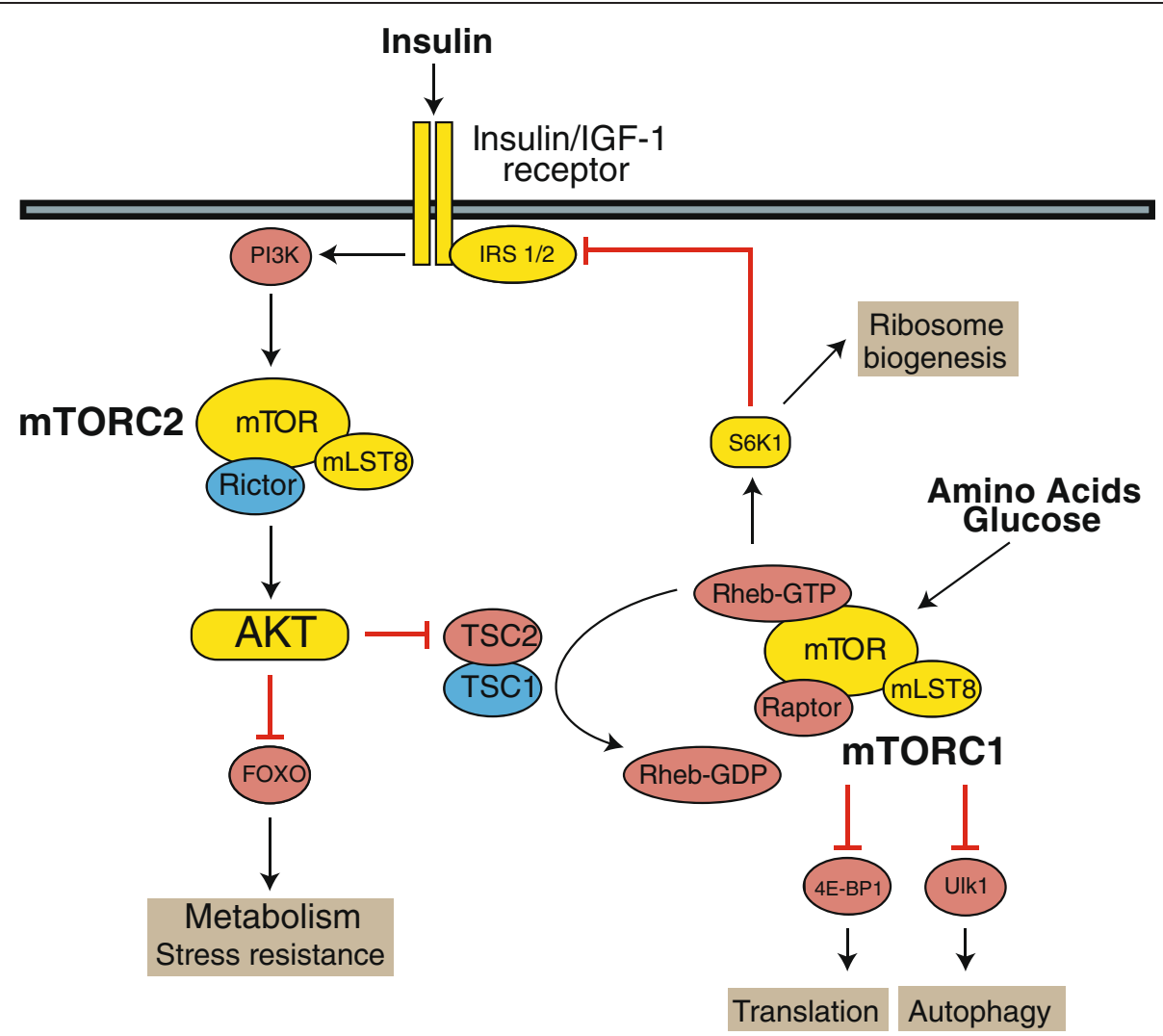

Figure 1 The PI3K/Akt/mTOR signaling pathway. Insulin, amino acids and glucose stimulate signaling through the PI3K/Akt/mTOR signaling pathway to regulate ribosomal biogenesis, translation, autophagy, and metabolism and stress resistance.

reported to extend lifespan include mice null for either Irs 1 or $S 6 K 1$, mice heterozygous for either Igf1r or Akt1, mice expressing a hypomorphic allele of mTOR, and mice heterozygous for both $m T O R$ and $m L S T 8$ (Selman et al. 2009, 2011; Lamming et al. 2012; Bokov et al. 2011; Wu et al. 2013; Nojima et al. 2013). Deletion of the insulin receptor specifically in adipose tissue (the FIRKO mouse) also extends lifespan (Bluher et al. 2003), as does deletion of insulin receptor substrate 2 (IRS2) specifically in the brain (Taguchi et al. 2007).

Although the insulin sensitivity model of CR would predict that all of the interventions noted above should display increased insulin sensitivity, only mice lacking S6K1 and the FIRKO mouse display increased insulin sensitivity and improved glucose tolerance. Mice heterozygous for $A k t 1$, mice expressing a hypomorphic allele of $m T O R$, and mice heterozygous for both $m T O R$ and $m L S T 8$ have essentially normal glucose homeostasis. Indeed, mice lacking Irs1 or that lack Irs 2 specifically in the brain become insulin resistant, while mice heterozygous for Igflr become glucose intolerant and insulin resistant with age (Garg et al. 2011). Mice treated with rapamycin, an FDA-approved immunosuppressive and anti-cancer agent, have a significant increase in lifespan, even when treatment is begun late in life (Harrison et al.
2009). While rapamycin was originally proposed to act as a CR mimetic, analysis of the effects of rapamycin on gene expression have revealed the two interventions to be quite distinct (Fok et al. 2014a). From the standpoint of glucose homeostasis and insulin sensitivity, rapamycin and CR have quite divergent effects, with rapamycin treatment resulting in glucose intolerance and hepatic insulin resistance (Lamming et al. 2012, 2013a). This clearly demonstrates that insulin sensitivity is not required for extended longevity - and that insulin resistance, although perhaps undesirable, is not sufficient to block extended longevity.

It is worth noting that not all genetic interventions in the PI3K/Akt/mTOR signaling pathway that decrease insulin sensitivity promote longevity. For instance, mice heterozygous for expression of the insulin receptor are insulin resistant, but do not have increased mean lifespan (Nelson et al. 2012). Indeed, the ultimate mechanism by which reduced mTOR signaling extends lifespan is unknown. The mTOR protein kinase is found in two distinct complexes (Figure 1), each with distinct functions and substrates. The canonical target of rapamycin is mTOR complex 1 (mTORC1), which is acutely sensitive to rapamycin and regulates ribosomal protein biogenesis, protein translation and autophagy. Extensive 
genetic studies in yeast and C. elegans have demonstrated that inhibition of protein translation or the activation of autophagy is sufficient to extend lifespan (reviewed in (Lamming et al. 2013b)). Deletion of TSC1 activates mTORC1, resulting in a significant decrease in lifespan due to liver hemangiomas (Kwiatkowski et al. 2002).

While these results suggest that mTORC1 is very important in the response to decreased PI3K/Akt/mTOR signaling, chronic rapamycin treatment also inhibits mTORC2 in vivo. Through regulation of key residues on AKT and SGK, mTORC2 regulates the FOXO and p38 MAPK pathways (Lamming et al. 2014). These pathways, in particular the FOXO proteins, are crucial in the regulation of lifespan and stress resistance in C. elegans, and siRNA knockdown of Rictor, an essential protein subunit of mTORC2, in C. elegans extends lifespan. However, male mice heterozygous for Rictor have a short lifespan despite normal glucose tolerance. The long life of mice heterozygous for $A k t 1$ is likely not attributable to activation of FOXO family members, and is instead likely due to decreased mTORC1 activity (Nojima et al. 2013). The role of mTORC2 in the regulation of lifespan is therefore uncertain, and may be mediated largely by its role as a modulator of mTORC1 signaling.

The clear conclusion to be drawn from these studies is that the insulin sensitivity explanation for the positive effects of a CR diet is naive. Instead, a common theme is that interventions in the PI3K/Akt/mTOR pathway that reduce mTORC1 activity significantly increase lifespan. While much attention has recently focused on rapamycin and genetic mutations in the mTOR complexes and their substrates, at the physiological level mTOR is regulated by a diverse set of physiological stimuli. Some of the most important of these are endocrine factors that collectively serve to coordinate PI3K/Akt/mTOR signaling in multiple tissues. We discuss some of the most important of these pathways below, and highlight opportunities and unanswered questions regarding many of these pathways.

Insulin-like Growth Factor 1 (IGF-1) signaling and longevity Signaling by insulin and the closely related hormones insulin-like growth factors 1 and 2 (IGF-1 and IGF-2) is mediated by hormone binding to the insulin receptor, the IGF-1 receptor, or hybrid insulin-IGF-1 receptor complexes (van Heemst 2010). Signaling through these receptors activates PI3K/Akt/mTOR signaling and regulates aging (Figure 2). Because of the shared nature of the receptors, which bind each hormone with different affinities, it can be difficult to determine relative contribution of each hormone to metabolic and lifespan effects. Nonetheless, a preponderance of evidence points to a specific role for IGF-1 in the regulation of lifespan in a manner dependent upon PI3K/ Akt/mTOR signaling.
IGF-1 is very strongly linked to lifespan, with multiple long-lived mouse models, including the Ames and Snell dwarf mice, the FIRKO mouse, and $I g f 1 r^{+/-}$mice showing decreased levels of IGF-1. Ames and Snell dwarf mice have a primary defect that results in low growth hormone production and therefore extremely low IGF-1 plasma levels (Brown-Borg and Bartke 2012), as well as reduced mTORC1 substrate phosphorylation (Sharp and Bartke 2005). Growth hormone receptor knockout mice have very similar phenotypes in terms of IGF-1 levels, and these mice also live longer. However, a recent publication using mice that produce less IGF-1 shows that while reducing IGF-1 levels in serum and tissue by approximately $50 \%$ extends maximum lifespan, it does not increase mean lifespan, suggesting that decreased IGF-1 levels do not fully explain the long lifespan of Ames and Snell dwarf mice (Lorenzini et al. 2014).

IGF-1 does not circulate freely in the blood; instead, circulating IGF-1 is almost always found bound to one of the IGF binding proteins (IGFBPs) which regulate the activity, bioavailability, and retention of IGF-1 (Boisclair et al. 2001). While many contemporary references refer to six IGFBPs, an additional member, IGFBP-7, was characterized almost 20 years ago (Oh et al. 1996). When IGF-1 is bound to either IGFBP-3 and IGFBP-5, a third protein, the acid labile subunit (ALS) is also recruited (Boisclair et al. 2001). The presence of the ALS is critically important in the maintenance of serum levels of IGF-1 and IGFBP3.

While it is clear that IGF-1 activity is regulated by the IGFBPs, this interaction has not yet been thoroughly explored with regard to the regulation of PI3K/Akt/mTOR signaling and lifespan, and individual IGFBPs may promote or inhibit IGF-1 activity (Figure 2). Mice lacking pregnancy-associated plasma protein A, a metalloproteinase that degrades inhibitory IGFBPs and thus increases IGF-1 signaling, have decreased IGF-1 signaling and a significantly extended lifespan (Conover and Bale 2007). With regards to specific IGFBPs, IGFBP2 appears to be the most interesting with regards to the regulation of insulin sensitivity. Igfbp2 expression is transcriptionally induced in response to leptin in liver and skeletal muscle, and acute overexpression of IGFBP-2 in the liver of $o b / o b$ mice significantly improves glucose tolerance and blood glucose and insulin levels (Hedbacker et al. 2010; Yau et al. 2014). While its role on PI3K/Akt/ mTOR signaling is unclear, it is actually induced by insulin via the PI3K/Akt/mTOR signaling pathway (Li et al. 2012). However, the effect of IGFBP2 expression on lifespan is not known; indeed, of the IGFBPs, only IGFBP7 has been shown to extend lifespan when overexpressed - in $D$. melanogaster (Alic et al. 2011). Understanding the role of the IGFBPs in mammalian lifespan is likely to prove an important area for future research. 


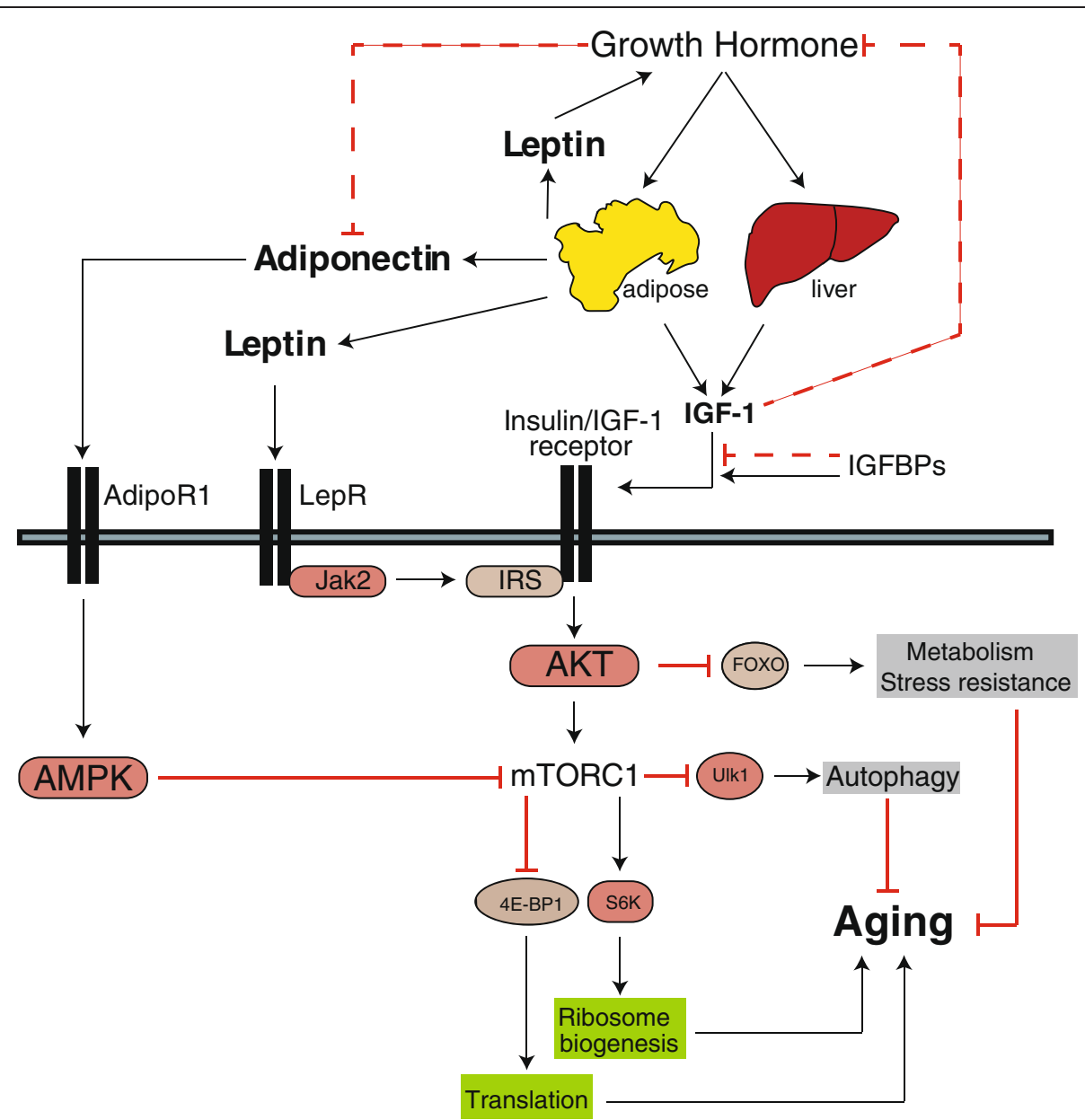

Figure 2 Regulation of PI3K/Akt/mTOR signaling by growth hormone, IGF-1, leptin and adiponectin. Growth hormone signaling promotes the expression of IGF-1 by the liver and adipose tissue, which signals through the insulin/IGF-1 receptor to promote PI3K/Akt/mTORC1 signaling and aging. Several mutant mice, such as the Ames Dwarf mouse, are deficient for the production of growth hormone, and consequently have low IGF-1 levels and low mTORC1 activity in IGF-1 sensitive tissues. Growth hormone also normally represses adiponectin, a hormone from white adipose tissue that inhibits mTORC1 activity by activating AMPK. Leptin promotes PI3K/Akt/mTOR signaling via the Jak2-mediated phosphorylation of insulin receptor substrate. Leptin also promotes IGF-1 signaling by stimulating the GH/IGF-1 axis. Functions such as translation and autophagy that impact aging are shown in a green box if stimulated by PI3K/Akt/mTORC1 activity, and gray box if inhibited by PI3K/Akt/ mTORC1 activity.

\section{Growth hormone and Adiponectin regulate PI3K/Akt/ mTOR signaling via distinct pathways}

The long lifespan of the Ames and Snell dwarf mice, which have a primary defect of impaired growth hormone production, strongly suggest that growth hormone (GH) regulates longevity. Growth hormone Receptor KnockOut (GhRKO) mice, which are unable to sense growth hormone, likewise have extended lifespan. It was discovered in 2005 that Ames dwarf mice have decreased PI3K/Akt/ mTOR signaling (Sharp and Bartke 2005), but it has not generally been appreciated that decreased mTOR signaling may be a major mechanism by which decreased levels of GH signaling extend lifespan. As shown in Figure 2, the effect of GH on PI3K/Akt/mTOR signaling is likely mediated in large part by decreased levels of IGF-1.
GH may also promote PI3K/Akt/mTOR signaling through IGF-1 independent pathways. For example, $\mathrm{GH}$ has profound effects on methionine metabolism (Brown-Borg and Rakoczy 2013), and amino acids regulate mTORC1 via the Rag family of GTPases (Bar-Peled and Sabatini 2014). GH directly modulates glucose uptake by skeletal muscle (Yakar et al. 2004), and glucose regulates mTORC1 signaling directly via the Rag family of GTPases (Efeyan et al. 2013). Another major effect of GH on physiology is altered lipid metabolism, with Ames dwarf mice showing significantly reduced levels of plasma free fatty acids and tissue triglyceride levels and decreased body fat in adults (Wang et al. 2006; Heiman et al. 2003). Reduced lipid levels could promote insulin sensitivity and thus impact PI3K/Akt/mTOR signaling. 
Adiponectin is a protein hormone secreted from white adipose tissue that is heavily implicated in the extension of lifespan, being increased in mice on a CR diet as well as GHRKO and Ames dwarf mice (Wang et al. 2006). It was first discovered as a hormone that is decreased in the serum of humans with type 2 diabetes, and that was increased upon weight loss (Hotta et al. 2000). Adiponectin exerts antidiabetic effects in part by increasing hepatic insulin sensitivity and decreasing skeletal muscle insulin resistance (Yamauchi et al. 2001; Berg et al. 2001). Adiponectin action is meditated by the adiponectin receptors AdipoR1, which activates AMPK, and AdipoR2, which activates the PPAR $\alpha$ signaling pathway. The increase in skeletal muscle insulin sensitivity is mediated by the activation of AMPK, which leads to the inhibition of mTORC1 (Figure 2), decreasing the activation of its substrate S6K1 and reducing the inhibitory serine phosphorylation of IRS1 (Wang et al. 2007). There is significant interest in adiponectin as a potential mediator of the beneficial effects of a CR diet, but ongoing studies have not conclusively linked adiponectin levels to longevity in humans (Stenholm et al. 2011).

Overexpression of adiponectin in mice leads to a significant increase in lifespan on both normal and high-fat diets (Otabe et al. 2007). Many of the metabolic effects of adiponectin overexpression are similar to those of Ames dwarf mice and GhRKO mice (Brown-Borg and Bartke 2012). Fascinatingly, decreasing the elevated adiponectin levels of GhRKO mice by surgical removal of the visceral fat depots leads to normalization of metabolic phenotypes associated with longevity, including insulin sensitivity, body temperature, and respiratory quotient (Masternak et al. 2012). It remains to be seen if this surgical intervention also normalizes the lifespan of GhRKO mice; however, it is apparent from genetic experiments that loss of GhR specifically in adipose tissue is not sufficient to increase adiponectin or increase insulin sensitivity (List et al. 2013). Investigation of PI3K/ Akt/mTOR signaling in these mouse models of normalized adiponectin expression may provide insight into the possible effects of these interventions on longevity.

One important distinction between the Ames dwarf mouse and the GhRKO mouse is that the long lifespan of the Ames dwarf mouse can be extended by a CR diet - an effect mediated by GH (Gesing et al. 2014) whereas GhRKO mice are largely insensitive to the effects of a CR diet on lifespan (Bonkowski et al. 2006). Notably, wild type mice placed on a CR diet have increased insulin sensitivity and decreased signaling to Akt, but these effects do not occur in GhRKO mice (Al-Regaiey et al. 2005). While it is not clear why the $\mathrm{GH}$ receptor is required for the effect of $\mathrm{CR}$, these results correlate with a model in which CR promotes lifespan via decreased PI3K/Akt/mTOR signaling.

\section{Leptin promotes PI3K/Akt/mTOR pathway signaling}

Understanding the source of hunger and satiety has been an area of significant research in the face of the obesity epidemic sweeping much of the world. Leptin, the most famous of the satiety hormones, is a hormone produced by white adipose tissue. Leptin was identified by positional cloning of the spontaneous mouse $o b$ mutation (Zhang et al. 1994), leading to the identification of a small serum protein that regulates energy expenditure and food intake (Halaas et al. 1995). By regulating food intake and obesity, leptin indirectly impacts insulin sensitivity, but emerging evidence suggests that leptin may also directly regulate insulin signaling. Expression of leptin receptor in neurons of the hypothalamic arcuate nucleus improves insulin sensitivity (Morton et al. 2005).

As outlined in Figure 2, it is now known that leptin activates the PI3K/Akt/mTOR signaling pathway via Jak2 mediated phosphorylation of insulin receptor substrate (Park and Ahima 2014). Leptin also promotes PI3K/Akt/ mTOR signaling via activation of the GH/IGF-1 axis (Watanobe and Habu 2002). The role of leptin in healthy aging and lifespan has been the subject of significant study. The dramatic phenotype of $o b / o b$ and $d b / d b$ mice that are deficient for leptin signaling clearly indicates that intact leptin signaling is required for healthy aging. Leptin resistance increases with age, and it has been suggested that diminished leptin action may be a cause of aging (Gabriely et al. 2002).

Leptin is reduced by a CR regimen (Schlitt and Schulz 2012), and the role of leptin in promoting PI3K/Akt/ mTOR activity (Figure 2) would lead us to predict that decreased leptin levels would be beneficial for lifespan. However, despite the positive effect of leptin on PI3K/ Akt/mTOR signaling, the net physiological consequence of leptin administration is a reduction in food intake and body weight (Halaas et al. 1997). Transgenic leptin mice have reduced food intake and an approximately $60 \%$ decrease in serum insulin levels (Qiu et al. 2001), which is likely to result in a net drop of PI3K/Akt/mTOR activity. The effect of leptin overexpression or lifelong administration of leptin on lifespan has not yet been examined. Leptin is a fascinating case in which the physiological context in which PI3K/Akt/mTOR pathway signaling is regulated may modify the net effect of the hormone on lifespan.

\section{The role of many other hormones in PI3K/Akt/mTOR and lifespan is not yet clear}

While the role of growth hormone, IGF-1, adiponectin, and leptin in the regulation of PI3K/Akt/mTOR signaling is becoming clear, there are many other metabolic regulatory hormones that may also play a role in the regulation of $\mathrm{PI} 3 \mathrm{~K} / \mathrm{Akt} / \mathrm{mTOR}$ pathway signaling and longevity. However, significant additional research will 
be required to elucidate these links. In the following section, we provide a brief introduction to resistin, ghrelin, cholecystokinin (CCK), glucagon like peptide 1 (GLP-1), the fibroblast growth factors, and humanin, all of which impinge upon glucose metabolism and insulin signaling, and are thus also candidate factors which may regulate PI3K/Akt/mTOR activity and thus regulate lifespan.

\section{Resistin}

Resistin is a protein hormone secreted by white adipose tissue, but in contrast to adiponectin, resistin acts to decrease insulin sensitivity (Steppan et al. 2001). Resistin was initially discovered in a screen for adipocyte genes responsive to treatment with the anti-diabetes drug rosiglitazone, and blocking the action of resistin with an antibody significantly increases glucose tolerance in mice. Resistin levels are decreased by a CR regimen in rats, likely mediated by GH and IGF-1 (Chiba et al. 2008), and are also decreased in the fat of GhRKO mice (Masternak et al. 2012). While longevity studies have not been performed with mice overexpressing or lacking resistin, a recent paper found that resistin impacts cholesterol metabolism by regulating the expression of low-density lipoprotein receptor (Melone et al. 2012), suggesting an important role for this hormone in healthspan.

\section{Ghrelin}

Ghrelin, the so-called "hunger hormone", is released primarily by endocrine cells in the stomach when the stomach is empty. Ghrelin acts as a neuropeptide that effectively antagonizes the action of leptin, and many of the same cells in the arcuate nucleus of the hypothalamus express both leptin and ghrelin receptors. However, ghrelin receptors are also expressed in other tissues (Geary 2004). Deletion of the receptor for ghrelin, the growth hormone secretagogue receptor, significantly improves insulin sensitivity during aging via the regulation of fat metabolism (Lin et al. 2011). Administration of ghrelin has some positive effects on the physiology of middle aged mice, reducing body weight primarily via a reduction in fat mass (Ariyasu et al. 2008). While no true lifespan study has been performed in healthy mice, it has been speculated that ghrelin might be an "antiaging hormone" (Maejima et al. 2011). However, a recent study has linked ghrelin signaling in the hypothalamus to the activation of mTORC1 (Stevanovic et al. 2013), which would lead us to predict (Figure 2) that ghrelin might actually promote aging. As with leptin, it is likely that thoroughly understanding the physiological context in which ghrelin regulates PI3K/Akt/mTOR signaling will be required to understand the role of ghrelin in longevity.

\section{Cholecystokinin}

Cholecystokinin (CCK) is a hormone released by duodenal I-cells that stimulate gallbladder contraction and pancreatic exocrine secretion, but it is also a neuropeptide that modulates satiety (Lavine et al. 2010; Dufresne et al. 2006). CCK receptor antagonists and agonists have attracted pharmaceutical company attention as a means of modulating feeding behavior, as well as treating pain and anxiety. With the exception of proglumide, a drug that inhibits gastric secretions and is used in ulcer treatment (Bergemann et al. 1981) CCK-based therapies have not successfully translated to the clinic. For example, the CCK agonist GI181771X was tested in clinical trials as a treatment for obesity, but humans taking GI181771X did not lose weight (Jordan et al. 2008).

CCK is actually a family of related peptides produced by processing of pre-pro-cholecystokinin, and are also often sulfated - in fact, sulfated CCK- 8 is the most bioactive form. It has been known since the 1980's that in addition to their role in satiety, CCK also plays a role in the regulation of glucose homeostasis, and CCK-8 stimulates insulin secretion in both rodents and humans (Ahren et al. 2000). CCK may also play an important role in the regulation of beta cell mass (Lavine et al. 2010; Linnemann et al. 2014). In pancreatic acinar cells, CCK promotes PI3K/Akt/mTOR signaling (Williams et al. 2002). OLETF rats, which have a spontaneously arising mutation in the CCK-A receptor, develop late onset hyperglycemia as well as diabetic nephropathy. OLETF rats have decreased cardiac IGF-1 expression as well as decreased phosphorylation of cardiac Akt (Makino et al. 2009). Although no longevity studies have been conducted with exogenously delivered CCK, it is therefore likely that CCK activates PI3K/Akt/mTOR signaling. However, CCK also acts synergistically with leptin to promote satiety, possibly by activating AMPK in the hypothalamus (Akieda-Asai et al. 2014), which may inhibit mTORC1 signaling. It therefore appears likely that the context in which CCK activation takes place may be important in understanding its effect on PI3K/Akt/mTOR activity.

\section{Glucagon-like peptide 1 (GLP-1)}

Glucagon-like peptide 1 (GLP-1) is a hormone derived from processing of the proglucagon gene product by the small intestine in response to nutrients. GLP-1 potently stimulates insulin secretion, but its activity is short-lived due to the action of dipeptidyl peptidase-4 (DPP4), a circulating enzyme which cleaves and inactivates GLP-1 (Kimple et al. 2014). Several drugs based on GLP-1 are now approved, including exenatide and liraglutide, GLP1 agonists that are resistant to cleavage by DPP4, and sitagliptin, an inhibitor of DPP4.

GLP-1 has shown success in reversing some of the phenotypes of aging, specifically in reversing the agerelated decline in glucose tolerance in aged rats (Wang et al. 1997). This effect is due in part to the effects of 
GLP-1 on beta cell function. GLP-1 administration increases insulin content and potentiates glucose stimulated insulin secretion in aged rats, while also stimulating increased beta cell mass and proliferation (Doyle and Egan 2001). Although no aging studies have been conducted with GLP-1 in healthy aged animals, GLP-1 has attracted some excitement as a possible therapy for diseases of neuronal injury, including Alzheimer's disease, stroke, Huntington's disease, and Parkinson's disease (Li et al. 2009, 2010; Martin et al. 2009). Indeed, two clinical trials of the GLP-1 agonist liraglutide in Alzheimer's disease are in progress; no results have yet been reported. Perhaps surprisingly for a drug with so many positive effects in neuronal injury models, liraglutide activates PI3K/Akt/mTORC1 signaling in beta cells (Miao et al. 2013). Understanding the mechanism by which GLP-1 agonists may promote healthspan and longevity is clearly a ripe area for future research.

\section{Fibroblast growth factors}

The role of fibroblast growth factors in aging was an unexpected discovery, arising from investigations into the ability of the Klotho gene to suppress aging (Kuro-o et al. 1997; Kurosu et al. 2005). It was noticed that the phenotypes of Klotho mutant mice - which include infertility, kyphosis, atherosclerosis, skin atrophy, muscle atrophy, T-cell dysregulation, pulmonary emphysema, altered phosphate and calcium metabolism, and shortened lifespan - are similar to the phenotype of mice lacking Fgf23 (Kurosu and Kuro 2009). This suggested that Klotho and FGF23 might function in the same pathway, and it was soon realized that Klotho and its homologue $\beta$ Klotho form complexes with FGF receptors, increasing the affinity of the receptor for FGF23 in the case of Klotho, and FGF15/19 and FGF21 in the case of $\beta$ Klotho (Kurosu and Kuro 2009). Although initially unclear, it is now believed that FGF23 does not play a vitamin D - independent role in either glucose homeostasis or aging (Streicher et al. 2012).

In contrast, FGF21 is well-established as an insulinsensitizing hormone produced in the liver in response to fasting or a CR diet (Kuhla et al. 2014). FGF21 antagonizes the GH-IGF1 signaling axis by in the liver by blocking Jak2/Stat5 signaling and suppressing the transcription of Igfl while also inducing Igfbpl (Inagaki et al. 2008). Mice that overexpress FGF21 have an approximately $30 \%$ increase in male lifespan, with female lifespan being extended by over 40\% (Zhang et al. 2012). They also have significantly improved glucose homeostasis, with lower fasting glucose and insulin levels, and improved whole body insulin sensitivity (Zhang et al. 2012). Surprisingly, FGF21 expression is positively mediated by PI3K/Akt signaling (Izumiya et al. 2008), and its expression does not increase during CR (Mendelsohn and Larrick 2012). Although FGF21 may be a partial CR mimetic, it likely functions via a distinct mechanism from the PI3K/Akt/mTORC1 signaling discussed above.

\section{Humanin}

Humanin is a short, 24-residue peptide originally identified as the result of a cDNA library screen for neuroprotective genes (Tajima et al. 2002). It was immediately noted that the open reading frame for humanin was identical to that of mitochondrial $16 \mathrm{~S}$ ribosomal RNA, resulting into some controversy as to whether the protein for humanin was expressed. Interestingly, although humanin binds to IGFBP-3 both in vitro and in vivo (Ikonen et al. 2003), research on the role of humanin remained focused on its potential role as a neuroprotective agent. However, as researchers began to explore the potential role of insulin resistance in the pathogenesis of Alzheimer's disease, it was found that humanin is also a central regulator of peripherial insulin sensitivity

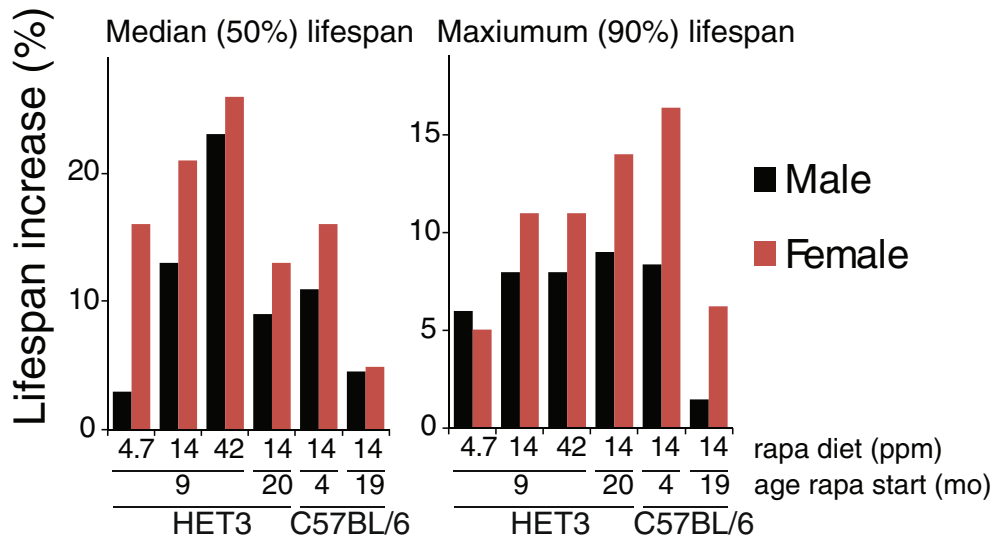

Figure 3 The sexually dimorphic effect of rapamycin treatment. Rapamycin consistently has a stronger effect on average and maximum female lifespan than on male lifespan in both HET3 and C57BL/6 mice. Data taken from (Zhang et al. 2014; Miller et al. 2014; Harrison et al. 2009; Fok et al. 2014b); median lifespan not available for HET3 mice initiated on 14ppm rapamycin at 20 months of age, mean is shown instead. 
(Muzumdar et al. 2009). Humanin also promotes beta cell survival in nonobsese diabetic (NOD) mice, delaying the onset of diabetes and improving glucose tolerance (Hoang et al. 2010). The actions of humanin on glucose homeostasis are likely mediated in part by its promotion of glucose stimulated insulin secretion by beta cells (Kuliawat et al. 2013).

While the effect of humanin on lifespan has not yet been determined, humanin and humanin analogues have shown efficacy in mouse models of cardiac injury, as well as positive effects on neuronal survival and memory in the mouse models of Alzheimer's disease, suggesting that humanin treatment may lead to increased longevity (Tajima et al. 2005; Muzumdar et al. 2010). It will be interesting to learn if humanin regulates PI3K/Akt/mTOR signaling, either directly or via modulation of IGF-1. Future study of humanin and other mitochondrial derived peptides are likely to lead to important biological discoveries in the biology of aging.

\section{Conclusions}

Herein, we have discussed some of the major endocrine factors that regulate glucose homeostasis and their effects - or possible effects - on longevity. We have presented a unifying model in which growth hormone, IGF1 , adiponectin, and leptin may all regulate lifespan via their effect on the PI3K/Akt/mTOR signaling pathway. While it remains to be conclusively proven, a CR diet may similarly act via decreased PI3K/Akt/mTOR signaling. Decreased fasting blood glucose and insulin levels are widely conserved effects of a CR diet in mammals (Lamming and Anderson 2014), and a CR diet significantly inhibits the PI3K/AKT/mTOR signaling pathway even in humans (Heilbronn et al. 2006; Mercken et al. 2013). At least some genetic mouse models of increased insulin sensitivity have a short lifespan (Nelson et al. 2012), again correlating with a model in which increased $\mathrm{PI}$ KK/AKT/mTOR signaling pathway activity acts to limit lifespan.

We have also briefly touched on a number of other endocrine factors that may regulate longevity via this same PI3K/Akt/mTOR signaling pathway. While some of these factors have established connections to PI3K/ Akt/mTOR signaling, future research will be required to learn if the others regulate this pathway. There are many other insulin sensitizing hormones we have not discussed, including prolactin, which regulates hepatic insulin sensitivity ( $\mathrm{Yu}$ et al. 2013) as well as beta cell function and mass (Park et al. 2012); the recently discovered meteorin-like which regulates beige fat thermogenesis (Rao et al. 2014); and the lipocalin family of hormones, which includes LCN2 (Rao et al. 2014), LCN13 (Zhou and Rui 2013), and Mup1 (Major urinary protein 1) (Zhou et al. 2009). While the role of these proteins in the regulation of lifespan and the PI3K/Akt/ mTOR signaling pathway is largely unknown, this area is ripe for study.

Finally, we have discussed that the context in which $\mathrm{PI} 3 \mathrm{~K} / \mathrm{Akt} / \mathrm{mTOR}$ signaling is regulated may be critical to understanding the effect on longevity. One of the most significant contexts is sex, and both genetic and pharmaceutical interventions in the insulin/IGF-1/ mTOR signaling pathway consistently show greater benefits in females than males. This sexual disparity in lifespan extension is observed in mice null for either Irs 1 or S6K1 (Selman et al. 2009, 2011), mice heterozygous for both $m T O R$ and $m L S T 8$ (Lamming et al. 2012), and consistently and across a range of doses in mice treated with rapamycin (Figure 3) (Miller et al. 2014). While the mechanistic and physiologic basis for this effect is unknown, $17 \beta$-estradiol plays a protective role against the development of rapamycin-induced diabetes, suggesting a possible contribution of sex hormones (Schindler et al. 2014). A deeper understanding the role of sex hormones and other endocrine factors in the PI3K/Akt/mTOR-dependent regulation of longevity will provide a platform for the development of interventions that can extend lifespan across the sexes and in a wide range of physiological contexts.

\section{Abbreviations}

CCK: Cholecystokinin; Fgf21: Fibroblast growth factor 21; GhRKO: Growth hormone receptor knockout; GLP-1: Glucagon-like peptide 1; IGF-1: Insulin-like growth factor 1; mTOR: Mechanistic target of rapamycin.

\section{Competing interests}

The author declares that he has no competing interests.

\section{Authors' contributions}

DWL wrote this review in its entirety.

\section{Acknowledgements}

This review benefited greatly from the advice of D.E. Cohen, and we also thank A.K. Linnemann for helpful suggestions about CCK and E.L. Baar for critical reading of the manuscript. The Lamming lab is supported by a grant from the National Institute of Health (AG041765) and startup funds from the UW-Madison School of Medicine and Public Health and the UW-Madison Department of Medicine. This work was supported using facilities and resources from the William S. Middleton Memorial Veterans Hospital. This work does not represent the views of the Department of Veterans Affairs or the United States Government.

Received: 5 November 2014 Accepted: 7 December 2014 Published: 15 December 2014

\section{References}

Ahren B, Holst JJ, Efendic S (2000) Antidiabetogenic action of cholecystokinin-8 in type 2 diabetes. J Clin Endocrinol Metab 85(3):1043-1048. doi:10.1210/jcem.85.3.6431

Akieda-Asai S, Poleni PE, Date Y (2014) Coinjection of CCK and leptin reduces food intake via increased CART/TRH and reduced AMPK phosphorylation in the hypothalamus. Am J Physiol Endocrinol Metab 306(11):E1284-E1291. doi:10.1152/ajpendo.00664.2013

Alic N, Hoddinott MP, Vinti G, Partridge L (2011) Lifespan extension by increased expression of the Drosophila homologue of the IGFBP7 tumour suppressor. Aging Cell 10(1):137-147. doi:10.1111/j.1474-9726.2010.00653.x 
Al-Regaiey KA, Masternak MM, Bonkowski M, Sun L, Bartke A (2005) Long-lived growth hormone receptor knockout mice: interaction of reduced insulin-like growth factor i/insulin signaling and caloric restriction. Endocrinology 146(2):851-860. doi:10.1210/en.2004-1120

Anderson RM, Weindruch R (2010) Metabolic reprogramming, caloric restriction and aging. Trends Endocrinol Metab 21(3):134-141. doi:10.1016/j.tem.2009.11.005

Ariyasu H, Iwakura H, Yamada G, Nakao K, Kangawa K, Akamizu T (2008) Efficacy of ghrelin as a therapeutic approach for age-related physiological changes. Endocrinology 149(7):3722-3728. doi:10.1210/en.2007-1650

Bar-Peled L, Sabatini DM (2014) Regulation of mTORC1 by amino acids. Trends Cell Biol 24(7):400-406. doi:10.1016/j.tcb.2014.03.003

Bartke A, Brown-Borg H (2004) Life extension in the dwarf mouse. Curr Top Dev Biol 63:189-225. doi:10.1016/S0070-2153(04)63006-7

Berg AH, Combs TP, Du X, Brownlee M, Scherer PE (2001) The adipocyte-secreted protein Acrp30 enhances hepatic insulin action. Nat Med 7(8):947-953. doi:10.1038/90992

Bergemann W, Consentius K, Braun HE, Hirschmann H, Marowski B, Munck A, Rehs HU, Stopik D, Wilke G (1981) Duodenal ulcer - multicenter double-blind study with proglumide. Med Klin 76(8):226-229

Bluher M, Kahn BB, Kahn CR (2003) Extended longevity in mice lacking the insulin receptor in adipose tissue. Science 299(5606):572-574 doi:10.1126/science.1078223

Boisclair YR, Rhoads RP, Ueki I, Wang J, Ooi GT (2001) The acid-labile subunit (ALS) of the $150 \mathrm{kDa}$ IGF-binding protein complex: an important but forgotten component of the circulating IGF system. J Endocrinol 170(1):63-70

Bokov AF, Garg N, Ikeno Y, Thakur S, Musi N, DeFronzo RA, Zhang N, Erickson RC, Gelfond J, Hubbard GB, Adamo ML, Richardson A (2011) Does reduced IGF-1R signaling in Igf1r+/- mice alter aging? PLoS One 6(11):e26891. doi:10.1371/journal.pone.0026891

Bonkowski MS, Rocha JS, Masternak MM, Al Regaiey KA, Bartke A (2006) Targeted disruption of growth hormone receptor interferes with the beneficial actions of calorie restriction. Proc Natl Acad Sci U S A 103(20):7901-7905. doi:10.1073/pnas.0600161103

Brown-Borg HM, Bartke A (2012) GH and IGF1: roles in energy metabolism of long-living GH mutant mice. J Gerontol A Biol Sci Med Sci 67(6):652-660. doi:10.1093/gerona/gls086

Brown-Borg HM, Rakoczy S (2013) Metabolic adaptations to short-term every-other-day feeding in long-living Ames dwarf mice. Exp Gerontol 48(9):905-919. doi:10.1016/j.exger.2013.06.009

Cartee GD, Kietzke EW, Briggs-Tung C (1994) Adaptation of muscle glucose transport with caloric restriction in adult, middle-aged, and old rats. Am J Physiol 266(5 Pt 2):R1443-R1447

Chiba T, Yamaza H, Komatsu T, Nakayama M, Fujita S, Hayashi H, Higami Y, Shimokawa I (2008) Pituitary growth hormone suppression reduces resistin expression and enhances insulin effectiveness: relationship with caloric restriction. Exp Gerontol 43(6):595-600. doi:10.1016/j.exger.2008.03.003

Conover CA, Bale LK (2007) Loss of pregnancy-associated plasma protein A extends lifespan in mice. Aging Cell 6(5):727-729. doi:10.1111/j.1474-9726.2007.00328.x

Doyle ME, Egan JM (2001) Glucagon-like peptide-1. Recent Prog Horm Res 56:377-399

Dufresne M, Seva C, Fourmy D (2006) Cholecystokinin and gastrin receptors Physiol Rev 86(3):805-847. doi:10.1152/physrev.00014.2005

Efeyan A, Zoncu R, Chang S, Gumper I, Snitkin H, Wolfson RL, Kirak O, Sabatini DD, Sabatini DM (2013) Regulation of mTORC1 by the Rag GTPases is necessary for neonatal autophagy and survival. Nature 493(7434):679-683. doi:10.1038/nature11745

Fok WC, Bokov A, Gelfond J, Yu Z, Zhang Y, Doderer M, Chen Y, Javors M, Wood WH, 3rd, Zhang Y, Becker KG, Richardson A, Perez VI (2014a) Combined treatment of rapamycin and dietary restriction has a larger effect on the transcriptome and metabolome of liver. Aging Cell 13(2):311-319. doi:10.1111/acel.12175

Fok WC, Chen Y, Bokov A, Zhang Y, Salmon AB, Diaz V, Javors M, Wood WH, 3rd, Zhang Y, Becker KG, Perez VI, Richardson A (2014b) Mice fed rapamycin have an increase in lifespan associated with major changes in the liver transcriptome. PLoS One 9(1):e83988. doi:10.1371/journal.pone.0083988

Gabriely I, Ma XH, Yang XM, Rossetti L, Barzilai N (2002) Leptin resistance during aging is independent of fat mass. Diabetes 51(4):1016-1021

Garg N, Thakur S, McMahan CA, Adamo ML (2011) High fat diet induced insulin resistance and glucose intolerance are gender-specific in IGF-1R heterozygous mice. Biochem Biophys Res Commun 413(3):476-480. doi:10.1016/j.bbrc.2011.08.123

Geary N (2004) Endocrine controls of eating: CCK, leptin, and ghrelin. Physiol Behav 81(5):719-733. dio:10.1016/j.physbeh.2004.04.013

Gesing A, Al-Regaiey KA, Bartke A, Masternak MM (2014) Growth hormone abolishes beneficial effects of calorie restriction in long-lived Ames dwarf mice. Exp Gerontol 58C:219-229. doi:10.1016/j.exger.2014.08.010

Halaas JL, Gajiwala KS, Maffei M, Cohen SL, Chait BT, Rabinowitz D, Lallone RL, Burley SK, Friedman JM (1995) Weight-reducing effects of the plasma protein encoded by the obese gene. Science 269(5223):543-546

Halaas JL, Boozer C, Blair-West J, Fidahusein N, Denton DA, Friedman JM (1997) Physiological response to long-term peripheral and central leptin infusion in lean and obese mice. Proc Natl Acad Sci U S A 94(16):8878-8883

Harrison DE, Strong R, Sharp ZD, Nelson JF, Astle CM, Flurkey K, Nadon NL, Wilkinson JE, Frenkel K, Carter CS, Pahor M, Javors MA, Fernandez E, Miller RA (2009) Rapamycin fed late in life extends lifespan in genetically heterogeneous mice. Nature 460(7253):392-395. doi:10.1038/nature08221

Hedbacker K, Birsoy K, Wysocki RW, Asilmaz E, Ahima RS, Farooqi IS, Friedman JM (2010) Antidiabetic effects of IGFBP2, a leptin-regulated gene. Cell Metab 11 (1):11-22. doi:10.1016/j.cmet.2009.11.007

Heilbronn LK, de Jonge L, Frisard MI, DeLany JP, Larson-Meyer DE, Rood J, Nguyen T, Martin CK, Volaufova J, Most MM, Greenway FL, Smith SR, Deutsch WA, Williamson DA, Ravussin E, Pennington CT (2006) Effect of 6-month calorie restriction on biomarkers of longevity, metabolic adaptation, and oxidative stress in overweight individuals: a randomized controlled trial. JAMA 295(13):1539-1548. doi:10.1001/jama.295.13.1539

Heiman ML, Tinsley FC, Mattison JA, Hauck S, Bartke A (2003) Body composition of prolactin-, growth hormone, and thyrotropin-deficient Ames dwarf mice. Endocrine 20(1-2):149-154. doi:10.1385/ENDO:20:1-2:149

Hoang PT, Park P, Cobb LJ, Paharkova-Vatchkova V, Hakimi M, Cohen P, Lee KW (2010) The neurosurvival factor Humanin inhibits beta-cell apoptosis via signal transducer and activator of transcription 3 activation and delays and ameliorates diabetes in nonobese diabetic mice. Metabolism 59(3):343-349. doi:10.1016/j.metabol.2009.08.001

Hotta K, Funahashi T, Arita Y, Takahashi M, Matsuda M, Okamoto Y, Iwahashi H, Kuriyama H, Ouchi N, Maeda K, Nishida M, Kihara S, Sakai N, Nakajima T, Hasegawa K, Muraguchi M, Ohmoto Y, Nakamura T, Yamashita S, Hanafusa T, Matsuzawa Y (2000) Plasma concentrations of a novel, adipose-specific protein, adiponectin, in type 2 diabetic patients. Arterioscler Thromb Vasc Biol 20(6):1595-1599

Ikonen M, Liu B, Hashimoto Y, Ma L, Lee KW, Niikura T, Nishimoto I, Cohen P (2003) Interaction between the Alzheimer's survival peptide humanin and insulin-like growth factor-binding protein 3 regulates cell survival and apoptosis. Proc Natl Acad Sci U S A 100(22):13042-13047. doi:10.1073/pnas.2135111100

Inagaki T, Lin VY, Goetz R, Mohammadi M, Mangelsdorf DJ, Kliewer SA (2008) Inhibition of growth hormone signaling by the fasting-induced hormone FGF21. Cell Metab 8(1):77-83. doi:10.1016/j.cmet.2008.05.006

Izumiya Y, Bina HA, Ouchi N, Akasaki Y, Kharitonenkov A, Walsh K (2008) FGF21 is an Akt-regulated myokine. FEBS Lett 582(27):3805-3810. doi:10.1016/j.febslet.2008.10.021

Jordan J, Greenway FL, Leiter LA, Li Z, Jacobson P, Murphy K, Hill J, Kler L, Aftring RP (2008) Stimulation of cholecystokinin-A receptors with Gl181771X does not cause weight loss in overweight or obese patients. Clin Pharmacol Ther 83(2):281-287. doi:10.1038/sj.clpt.6100272

Kemnitz JW, Roecker EB, Weindruch R, Elson DF, Baum ST, Bergman RN (1994) Dietary restriction increases insulin sensitivity and lowers blood glucose in rhesus monkeys. Am J Physiol 266(4 Pt 1):E540-E547

Kimple ME, Neuman JC, Linnemann AK, Casey PJ (2014) Inhibitory G proteins and their receptors: emerging therapeutic targets for obesity and diabetes. Exp Mol Med 46:e102. doi:10.1038/emm.2014.40

Kuhla A, Hahn S, Butschkau A, Lange S, Wree A, Vollmar B (2014) Lifelong caloric restriction reprograms hepatic fat metabolism in mice. J Gerontol A Biol Sci Med Sci 69(8):915-922. doi:10.1093/gerona/glt160

Kuliawat R, Klein L, Gong Z, Nicoletta-Gentile M, Nemkal A, Cui L, Bastie C, Su K, Huffman D, Surana M, Barzilai N, Fleischer N, Muzumdar R (2013) Potent humanin analog increases glucose-stimulated insulin secretion through enhanced metabolism in the beta cell. FASEB J 27(12):4890-4898. doi:10.1096/fj.13-231092

Kuro-o M, Matsumura Y, Aizawa H, Kawaguchi H, Suga T, Utsugi T, Ohyama Y, Kurabayashi M, Kaname T, Kume E, Iwasaki H, lida A, Shiraki-lida T, Nishikawa 
S, Nagai R, Nabeshima YI (1997) Mutation of the mouse klotho gene leads to a syndrome resembling ageing. Nature 390(6655):45-51. doi:10.1038/36285

Kurosu H, Kuro OM (2009) The Klotho gene family as a regulator of endocrine fibroblast growth factors. Mol Cell Endocrinol 299(1):72-78. doi:10.1016/j.mce.2008.10.052

Kurosu H, Yamamoto M, Clark JD, Pastor JV, Nandi A, Gurnani P, McGuinness OP, Chikuda H, Yamaguchi M, Kawaguchi H, Shimomura I, Takayama Y, Herz J, Kahn CR, Rosenblatt KP, Kuro-o M (2005) Suppression of aging in mice by the hormone Klotho. Science 309(5742):1829-1833. doi:10.1126/science.1112766

Kwiatkowski DJ, Zhang H, Bandura JL, Heiberger KM, Glogauer M, el-Hashemite $\mathrm{H}$, Onda $\mathrm{H}$ (2002) A mouse model of TSC1 reveals sex-dependent lethality from liver hemangiomas, and up-regulation of p70S6 kinase activity in Tsc1 null cells. Hum Mol Genet 11(5):525-534

Lamming DW, Anderson RM (2014) Metabolic Effects of Caloric Restriction. In: eLS. John Wiley \& Sons, Ltd, Chichester. doi:10.1002/9780470015902. a0021316.pub2

Lamming DW, Ye L, Katajisto P, Goncalves MD, Saitoh M, Stevens DM, Davis JG, Salmon AB, Richardson A, Ahima RS, Guertin DA, Sabatini DM, Baur JA (2012) Rapamycin-induced insulin resistance is mediated by mTORC2 loss and uncoupled from longevity. Science 335(6076):1638-1643. doi:10.1126/science.1215135

Lamming DW, Ye L, Astle CM, Baur JA, Sabatini DM, Harrison DE (2013a) Young and old genetically heterogeneous HET3 mice on a rapamycin diet are glucose intolerant but insulin sensitive. Aging Cell 12(4):712-718. doi:10.1111/acel.12097

Lamming DW, Ye L, Sabatini DM, Baur JA (2013b) Rapalogs and mTOR inhibitors as anti-aging therapeutics. J Clin Invest 123(3):980-989. doi:10.1172/JCl64099

Lamming DW, Demirkan G, Boylan JM, Mihaylova MM, Peng T, Ferreira J, Neretti N, Salomon A, Sabatini DM, Gruppuso PA (2014) Hepatic signaling by the mechanistic target of rapamycin complex 2 (mTORC2). FASEB J 28(1):300-315. doi:10.1096/fj.13-237743

Lavine JA, Raess PW, Stapleton DS, Rabaglia ME, Suhonen JI, Schueler KL, Koltes JE, Dawson JA, Yandell BS, Samuelson LC, Beinfeld MC, Davis DB, Hellerstein MK, Keller MP, Attie AD (2010) Cholecystokinin is up-regulated in obese mouse islets and expands beta-cell mass by increasing beta-cell survival. Endocrinology 151(8):3577-3588. doi:10.1210/en.2010-0233

Li Y, Perry T, Kindy MS, Harvey BK, Tweedie D, Holloway HW, Powers K, Shen H, Egan JM, Sambamurti K, Brossi A, Lahiri DK, Mattson MP, Hoffer BJ, Wang Y, Greig NH (2009) GLP-1 receptor stimulation preserves primary cortical and dopaminergic neurons in cellular and rodent models of stroke and Parkinsonism. Proc Natl Acad Sci U S A 106(4):1285-1290. doi:10.1073/pnas.0806720106

Li Y, Duffy KB, Ottinger MA, Ray B, Bailey JA, Holloway HW, Tweedie D, Perry T, Mattson MP, Kapogiannis D, Sambamurti K, Lahiri DK, Greig NH (2010) GLP-1 receptor stimulation reduces amyloid-beta peptide accumulation and cytotoxicity in cellular and animal models of Alzheimer's disease. J Alzheimers Dis 19(4):1205-1219. doi:10.3233/JAD-2010-1314

Li Z, Miard S, Laplante M, Sonenberg N, Picard F (2012) Insulin stimulates IGFBP-2 expression in 3T3-L1 adipocytes through the PI3K/mTOR pathway. Mol Cell Endocrinol 358(1):63-68. doi:10.1016/j.mce.2012.02.022

Lin L, Saha PK, Ma X, Henshaw IO, Shao L, Chang BH, Buras ED, Tong Q, Chan L, McGuinness OP, Sun Y (2011) Ablation of ghrelin receptor reduces adiposity and improves insulin sensitivity during aging by regulating fat metabolism in white and brown adipose tissues. Aging Cell 10(6):996-1010. doi:10.1111/j.1474-9726.2011.00740.x

Linnemann AK, Baan M, Davis DB (2014) Pancreatic beta-cell proliferation in obesity. Adv Nutr 5(3):278-288. doi:10.3945/an.113.005488

List EO, Berryman DE, Funk K, Gosney ES, Jara A, Kelder B, Wang X, Kutz L, Troike K, Lozier N, Mikula V, Lubbers ER, Zhang H, Vesel C, Junnila RK, Frank SJ, Masternak MM, Bartke A, Kopchick JJ (2013) The role of GH in adipose tissue: lessons from adipose-specific GH receptor gene-disrupted mice. Mol Endocrinol 27(3):524-535. doi:10.1210/me.2012-1330

Lorenzini A, Salmon AB, Lerner C, Torres C, lkeno Y, Motch S, McCarter R, Sell C (2014) Mice producing reduced levels of insulin-like growth factor type 1 display an increase in maximum, but not mean, life span. J Gerontol A Biol Sci Med Sci 69(4):410-419. doi:10.1093/gerona/glt108

Maejima Y, Kohno D, Iwasaki Y, Yada T (2011) Insulin suppresses ghrelin-induced calcium signaling in neuropeptide $Y$ neurons of the hypothalamic arcuate nucleus. Aging (Albany NY) 3(11):1092-1097

Makino N, Maeda T, Oyama J, Higuchi Y, Mimori K (2009) Improving insulin sensitivity via activation of PPAR-gamma increases telomerase activity in the heart of OLETF rats. Am J Physiol Heart Circ Physiol 297(6):H2188-H2195. doi:10.1152/ajpheart.00421.2009

Martin B, Golden E, Carlson OD, Pistell P, Zhou J, Kim W, Frank BP, Thomas S, Chadwick WA, Greig NH, Bates GP, Sathasivam K, Bernier M, Maudsley S, Mattson MP, Egan JM (2009) Exendin-4 improves glycemic control, ameliorates brain and pancreatic pathologies, and extends survival in a mouse model of Huntington's disease. Diabetes 58(2):318-328. doi:10.2337/db08-0799

Masternak MM, Bartke A, Wang F, Spong A, Gesing A, Fang Y, Salmon AB, Hughes LF, Liberati T, Boparai R, Kopchick JJ, Westbrook R (2012) Metabolic effects of intra-abdominal fat in GHRKO mice. Aging Cell 11(1):73-81. dio:10.1111/j.1474-9726.2011.00763.x

McCay CM, Maynard LA, Sperling G, Barnes LL (1939) Retarded growth, life span, ultimate body size and age changes in the albino rat after feeding diets restricted in calories. J Nutr 18:1-13

Melone M, Wilsie L, Palyha O, Strack A, Rashid S (2012) Discovery of a new role of human resistin in hepatocyte low-density lipoprotein receptor suppression mediated in part by proprotein convertase subtilisin/kexin type 9. J Am Coll Cardiol 59(19):1697-1705. doi:10.1016/j.jacc.2011.11.064

Mendelsohn AR, Larrick JW (2012) Fibroblast growth factor-21 is a promising dietary restriction mimetic. Rejuvenation Res 15(6):624-628. doi:10.1089/rej.2012.1392

Mercken EM, Crosby SD, Lamming DW, JeBailey L, Krzysik-Walker S, Villareal DT, Capri M, Franceschi C, Zhang Y, Becker K, Sabatini DM, de Cabo R, Fontana L (2013) Calorie restriction in humans inhibits the PI3K/AKT pathway and induces a younger transcription profile. Aging Cell 12(4):645-651. doi:10.1111/acel.12088

Miao XY, Gu ZY, Liu P, Hu Y, Li L, Gong YP, Shu H, Liu Y, Li CL (2013) The human glucagon-like peptide- 1 analogue liraglutide regulates pancreatic beta-cell proliferation and apoptosis via an AMPK/mTOR/P70S6K signaling pathway. Peptides 39:71-79. doi:10.1016/.jpeptides.2012.10.006

Miller RA, Harrison DE, Astle CM, Fernandez E, Flurkey K, Han M, Javors MA, Li X, Nadon NL, Nelson JF, Pletcher S, Salmon AB, Sharp ZD, Van Roekel S, Winkleman L, Strong R (2014) Rapamycin-mediated lifespan increase in mice is dose and sex dependent and metabolically distinct from dietary restriction. Aging Cell 13(3):468-477. doi:10.1111/acel.12194

Morton GJ, Gelling RW, Niswender KD, Morrison CD, Rhodes CJ, Schwartz MW (2005) Leptin regulates insulin sensitivity via phosphatidylinositol-3-OH kinase signaling in mediobasal hypothalamic neurons. Cell Metab 2(6):411-420. doi:10.1016/..cmet.2005.10.009

Muzumdar RH, Huffman DM, Atzmon G, Buettner C, Cobb L, Fishman S, Budagov T, Cui L, Einstein FH, Poduval A, Hwang D, Barzilai N, Cohen P (2009) Humanin: a novel central regulator of peripheral insulin action. PLoS One 4(7):e6334. doi:10.1371/journal.pone.0006334

Muzumdar RH, Huffman DM, Calvert JW, Jha S, Weinberg Y, Cui L, Nemkal A, Atzmon G, Klein L, Gundewar S, Ji SY, Lavu M, Predmore BL, Lefer DJ (2010) Acute humanin therapy attenuates myocardial ischemia and reperfusion injury in mice. Arterioscler Thromb Vasc Biol 30(10):1940-1948. doi:10.1161/ATVBAHA.110.205997

Nelson JF, Strong R, Bokov A, Diaz V, Ward W (2012) Probing the relationship between insulin sensitivity and longevity using genetically modified mice. J Gerontol A Biol Sci Med Sci 67(12):1332-1338. doi:10.1093/gerona/gls199

Nojima A, Yamashita M, Yoshida Y, Shimizu I, Ichimiya H, Kamimura N, Kobayashi Y, Ohta S, Ishii N, Minamino T (2013) Haploinsufficiency of akt1 prolongs the lifespan of mice. PLoS One 8(7):e69178. doi:10.1371/journal.pone.0069178

Oh Y, Nagalla SR, Yamanaka Y, Kim HS, Wilson E, Rosenfeld RG (1996) Synthesis and characterization of insulin-like growth factor-binding protein (IGFBP)-7. Recombinant human mac25 protein specifically binds IGF-I and -II. J Biol Chem 271(48):30322-30325

Olefsky JM, Glass CK (2010) Macrophages, inflammation, and insulin resistance Annu Rev Physiol 72:219-246. doi:10.1146/annurev-physiol-021909-135846

Otabe S, Yuan X, Fukutani T, Wada N, Hashinaga T, Nakayama H, Hirota N, Kojima M, Yamada K (2007) Overexpression of human adiponectin in transgenic mice results in suppression of fat accumulation and prevention of premature death by high-calorie diet. Am J Physiol Endocrinol Metab 293(1):E210-E218. doi:10.1152/ajpendo.00645.2006

Park HK, Ahima RS (2014) Leptin signaling. F1000Prime Rep 6(73):6-73. doi:10.12703

Park S, Kang S, Lee HW, Ko BS (2012) Central prolactin modulates insulin sensitivity and insulin secretion in diabetic rats. Neuroendocrinology 95(4):332-343. doi:10.1159/000336501 
Qiu J, Ogus S, Lu R, Chehab FF (2001) Transgenic mice overexpressing leptin accumulate adipose mass at an older, but not younger, age. Endocrinology 142(1):348-358. doi:10.1210/endo.142.1.7909

Rao RR, Long JZ, White JP, Svensson KJ, Lou J, Lokurkar I, Jedrychowski MP, Ruas JL, Wrann CD, Lo JC, Camera DM, Lachey J, Gygi S, Seehra J, Hawley JA, Spiegelman BM (2014) Meteorin-like is a hormone that regulates immune-adipose interactions to increase beige fat thermogenesis. Cell 157(6):1279-1291. doi:10.1016/..cell.2014.03.065

Schindler CE, Partap U, Patchen BK, Swoap SJ (2014) Chronic rapamycin treatment causes diabetes in male mice. Am J Physiol Regul Integr Comp Physiol 307(4):R434-R443. doi:10.1152/ajpregu.00123.2014

Schlitt JM, Schulz LC (2012) The source of leptin, but not leptin depletion in response to food restriction, changes during early pregnancy in mice. Endocrine 41(2):227-235. doi:10.1007/s12020-011-9548-0

Selman C, Tullet JM, Wieser D, Irvine E, Lingard SJ, Choudhury Al, Claret M, Al-Qassab H, Carmignac D, Ramadani F, Woods A, Robinson IC, Schuster E, Batterham RL, Kozma SC, Thomas G, Carling D, Okkenhaug K, Thornton JM, Partridge L, Gems D, Withers DJ (2009) Ribosomal protein S6 kinase 1 signaling regulates mammalian life span. Science 326(5949):140-144. doi:10.1126/science.1177221

Selman C, Partridge L, Withers DJ (2011) Replication of extended lifespan phenotype in mice with deletion of insulin receptor substrate 1. PLoS One 6(1):e16144. doi:10.1371/journal.pone.0016144

Sharp ZD, Bartke A (2005) Evidence for down-regulation of phosphoinositide 3-kinase/Akt/mammalian target of rapamycin (PI3K/Akt/mTOR)-dependent translation regulatory signaling pathways in Ames dwarf mice. J Gerontol A Biol Sci Med Sci 60(3):293-300

Sinclair DA (2005) Toward a unified theory of caloric restriction and longevity regulation. Mech Ageing Dev 126(9):987-1002. doi:10.1016/j.mad.2005.03.019

Stenholm S, Metter EJ, Roth GS, Ingram DK, Mattison JA, Taub DD, Ferrucci L (2011) Relationship between plasma ghrelin, insulin, leptin, interleukin 6, adiponectin, testosterone and longevity in the Baltimore Longitudinal Study of Aging. Aging Clin Exp Res 23(2):153-158

Steppan CM, Bailey ST, Bhat S, Brown EJ, Banerjee RR, Wright CM, Patel HR, Ahima RS, Lazar MA (2001) The hormone resistin links obesity to diabetes. Nature 409(6818):307-312. doi:10.1038/35053000

Stevanovic D, Trajkovic V, Muller-Luhlhoff S, Brandt E, Abplanalp W, Bumke-Vogt C, Liehl B, Wiedmer P, Janjetovic K, Starcevic V, Pfeiffer AF, Al-Hasani H, Tschop MH, Castaneda TR (2013) Ghrelin-induced food intake and adiposity depend on central mTORC1/S6K1 signaling. Mol Cell Endocrinol 381(1-2):280-290. doi:10.1016/j.mce.2013.08.009

Streicher C, Zeitz U, Andrukhova O, Rupprecht A, Pohl E, Larsson TE, Windisch W, Lanske B, Erben RG (2012) Long-term Fgf23 deficiency does not influence aging, glucose homeostasis, or fat metabolism in mice with a nonfunctioning vitamin D receptor. Endocrinology 153(4):1795-1805. doi:10.1210/en.2011-1878

Taguchi A, Wartschow LM, White MF (2007) Brain IRS2 signaling coordinates life span and nutrient homeostasis. Science 317(5836):369-372. doi:10.1126/science.1142179

Tajima H, Niikura T, Hashimoto Y, Ito Y, Kita Y, Terashita K, Yamazaki K, Koto A, Aiso S, Nishimoto I (2002) Evidence for in vivo production of Humanin peptide, a neuroprotective factor against Alzheimer's disease-related insults. Neurosci Lett 324(3):227-231

Tajima H, Kawasumi M, Chiba T, Yamada M, Yamashita K, Nawa M, Kita Y, Kouyama K, Aiso S, Matsuoka M, Niikura T, Nishimoto I (2005) A humanin derivative, S14G-HN, prevents amyloid-beta-induced memory impairment in mice. J Neurosci Res 79(5):714-723. doi:10.1002/jnr.20391

van Heemst D (2010) Insulin, IGF-1 and longevity. Aging Dis 1(2):147-157

Wang Y, Perfetti R, Greig NH, Holloway HW, DeOre KA, Montrose-Rafizadeh C, Elahi D, Egan JM (1997) Glucagon-like peptide-1 can reverse the age-related decline in glucose tolerance in rats. J Clin Invest 99(12):2883-2889. doi:10.1172/JCI119482

Wang Z, Al-Regaiey KA, Masternak MM, Bartke A (2006) Adipocytokines and lipid levels in Ames dwarf and calorie-restricted mice. J Gerontol A Biol Sci Med Sci 61(4):323-331

Wang C, Mao X, Wang L, Liu M, Wetzel MD, Guan KL, Dong LQ, Liu F (2007) Adiponectin sensitizes insulin signaling by reducing p70 S6 kinase-mediated serine phosphorylation of IRS-1. J Biol Chem 282(11):7991-7996. doi:10.1074/jbc.M700098200

Watanobe H, Habu S (2002) Leptin regulates growth hormone-releasing factor, somatostatin, and alpha-melanocyte-stimulating hormone but not neuropeptide $Y$ release in rat hypothalamus in vivo: relation with growth hormone secretion. J Neurosci 22(14):6265-6271. doi:20026615

Williams JA, Sans MD, Tashiro M, Schafer C, Bragado MJ, Dabrowski A (2002) Cholecystokinin activates a variety of intracellular signal transduction mechanisms in rodent pancreatic acinar cells. Pharmacol Toxicol 91(6):297-303

Wu JJ, Liu J, Chen EB, Wang JJ, Cao L, Narayan N, Fergusson MM, Rovira II, Allen M, Springer DA, Lago CU, Zhang S, DuBois W, Ward T, deCabo R, Gavrilova O, Mock B, Finkel T (2013) Increased mammalian lifespan and a segmental and tissue-specific slowing of aging after genetic reduction of mTOR expression. Cell Rep 4(5):913-920. doi:10.1016/j.celrep.2013.07.030

Yakar S, Setser J, Zhao H, Stannard B, Haluzik M, Glatt V, Bouxsein ML, Kopchick $\mathrm{JJ}$, LeRoith D (2004) Inhibition of growth hormone action improves insulin sensitivity in liver IGF-1-deficient mice. J Clin Invest 113(1):96-105. doi:10.1172/JCl17763

Yamauchi T, Kamon J, Waki H, Terauchi Y, Kubota N, Hara K, Mori Y, Ide T, Murakami K, Tsuboyama-Kasaoka N, Ezaki O, Akanuma Y, Gavrilova O, Vinson C, Reitman ML, Kagechika H, Shudo K, Yoda M, Nakano Y, Tobe K, Nagai R, Kimura S, Tomita M, Froguel P, Kadowaki T (2001) The fat-derived hormone adiponectin reverses insulin resistance associated with both lipoatrophy and obesity. Nat Med 7(8):941-946. doi:10.1038/90984

Yau SW, Henry BA, Russo VC, McConell GK, Clarke IJ, Werther GA, Sabin MA (2014) Leptin Enhances Insulin Sensitivity by Direct and Sympathetic Nervous System Regulation of Muscle IGFBP-2 Expression: Evidence From Nonrodent Models. Endocrinology 155(6):2133-2143. doi:10.1210/en.2013-2099

Yu J, Xiao F, Zhang Q, Liu B, Guo Y, Lv Z, Xia T, Chen S, Li K, Du Y, Guo F (2013) PRLR regulates hepatic insulin sensitivity in mice via STAT5. Diabetes 62(9):3103-3113. doi:10.2337/db13-0182

Zhang Y, Proenca R, Maffei M, Barone M, Leopold L, Friedman JM (1994) Positional cloning of the mouse obese gene and its human homologue. Nature 372(6505):425-432. doi:10.1038/372425a0

Zhang Y, Xie Y, Berglund ED, Coate KC, He TT, Katafuchi T, Xiao G, Potthoff MJ, Wei W, Wan Y, Yu RT, Evans RM, Kliewer SA, Mangelsdorf DJ (2012) The starvation hormone, fibroblast growth factor-21, extends lifespan in mice. Elife 1:e00065. doi:10.7554/eLife.00065

Zhang Y, Bokov A, Gelfond J, Soto V, Ikeno Y, Hubbard G, Diaz V, Sloane L, Maslin K, Treaster S, Rendon S, van Remmen H, Ward W, Javors M, Richardson A, Austad SN, Fischer K (2014) Rapamycin extends life and health in C57BL/6 mice. J Gerontol A Biol Sci Med Sci 69(2):119-130. doi:10.1093/gerona/glt056

Zhou Y, Rui L (2013) Lipocalin 13 regulation of glucose and lipid metabolism in obesity. Vitam Horm 91:369-383. doi:10.1016/B978-0-12-407766-9.00015-8

Zhou Y, Jiang L, Rui L (2009) Identification of MUP1 as a regulator for glucose and lipid metabolism in mice. J Biol Chem 284(17):11152-11159. doi:10.1074/jbc.M900754200

\section{doi:10.1186/2193-1801-3-735}

Cite this article as: Lamming: Diminished mTOR signaling: a common mode of action for endocrine longevity factors. SpringerPlus 2014 3:735.

\section{Submit your manuscript to a SpringerOpen ${ }^{\circ}$ journal and benefit from:}

- Convenient online submission

- Rigorous peer review

- Immediate publication on acceptance

- Open access: articles freely available online

High visibility within the field

- Retaining the copyright to your article

Submit your next manuscript at $>$ springeropen.com 